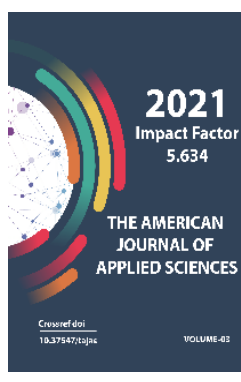

Journal Website: http://usajournalshub.c om/index,php/tajas

Copyright: Original content from this work may be used under the terms of the creative commons attributes 4.0 licence.

\section{The Role Of Hotel Industry In The Development Of The Economy Of Our Country And The Theoretical Issues Of Their Study}

Rakhimov Hasan Abdusaidovich

PhD, Teacher Of The Department Of Economic Analysis And Statistics, Samarkand Institute Of Economics And Service, Uzbekistan

\title{
ABSTRACT
}

This article describes the conceptual directions of improving the quality of service in hotels and scientific-theoretical and methodological issues of its evaluation. It shows the factors affecting the quality of hotel services, the specifics of hotel services, the system of indicators that reflect the quality of service in hotels, the content and ways to determine them.

\section{KEYWORDS}

Hotel, service, quality, quality of service, quality of service in hotels, a system of indicators representing the quality of service in hotels.

\section{INTRODUCTION}

Tourism and hotel management are components of an industry. The growing demand for hotels is directly related to the development of tourism. The expansion of hotel activities does not happen by itself. It is known from the world practice that the development of tourism leads to the growth of the country's economy, the development of underdeveloped regions, the growth of 
employment, the growth of the culture of the population.

Tourism is an industry in which the economy of the country develops, and the social life of the country improves. As a result, many countries have become tourist centers. The economic development of such countries is mainly due to tourism. The hotel management system, which is an integral part of the industry, has also been formed as a network.

It is known that our country has a great tourist potential. This is a huge opportunity to boost the economy. However, such opportunities have not been fully exploited. According to some scientists and the media, the share of tourism in the country's GDP is $1.8 \%$. However, the share of this indicator is much higher in developed countries. For example, 12\% in Spain, $10 \%$ in the Arab Republic of Egypt, $8 \%$ in Greece, $8 \%$ in the Federal Republic of Germany, $6-7 \%$ in France, $6.2 \%$ in India, $5 \%$ in Singapore, Belgium, USA $3 \%^{2}$. It is obvious that our country, which has rich tourist resources, still has great potential for the development of tourism and the hotel industry.

Another important aspect of the development of this sector for Uzbekistan is that it is also a decisive factor in the employment of the

1 Kudratov G'.H., Musaev H.H. Uzbekistan's investment policy and its role in the development of the tourism services market. // Socio-economic problems of tourism market development in Uzbekistan. Monograph. - T .: "Economy" Publishing House, 2012. - Pages 288-289.

2 Kudratov G'.H., Musaev H.H. Uzbekistan's investment policy and its role in the development of the tourism services market. // Socio-economic problems of tourism market development in Uzbekistan. Monograph. - T .: "Economy" Publishing House, 2012. - Pages 288-289. This information is also given in the monograph Pardaev MK, Khalikulov AN, Rakhimov HA "Problems of increasing efficiency in unemployed in rural areas of the country. This is because many traditional types of services that are attractive to private entrepreneurship are gradually developing in both urban and rural areas. However, until recently, no effective measures have been taken for the development of tourism and hotel industry in rural areas. In this regard, on April 17, 2006 the President of the Republic of Uzbekistan adopted a resolution "On measures to accelerate the development of the service sector in the Republic of Uzbekistan in 20062010."

In this decision, he gave a strong task to the local authorities, which was a great impetus for the development of the industry. In particular, the resolution reads: "It is absolutely intolerable that the heads of local authorities do not pay enough attention to this important sector"', it was pointed out. Of course, the efficiency of the neglected industry will also be commensurate. The share of the service sector in GDP in 2005 was $38.3 \%$. By 2010, this figure was set at 49.0 percent, and we have achieved this. But this is still rare. Because, as we have seen above, in the developed countries of the world, the share of service industries in GDP is $60-80 \% .70 \%$ of the population employed in the economy of these countries work in this service sector 5 .

the hotel industry" (T .: "Economy" Publishing House, 2013. - p. 44).

${ }^{3}$ Resolution of the President of the Republic of Uzbekistan dated April 17, 2006 "On measures to accelerate the development of the service sector in the Republic of Uzbekistan in 2006-2010". "People's word". April 18, 2006. p.1.

${ }^{4}$ Statistical Bulletin of Uzbekistan. 2005. Page 5.

${ }^{5}$ Khalikulov N.N. Opportunities to improve the quality and efficiency of service in hotels. Dissertation for the degree of Candidate of Economic Sciences. SamISI. - 2011. - Page 11, Pardaev M.Q., Khalikulov A.N., Rahimov H.A. Problems of increasing efficiency in hotel farms. 
The underdevelopment of the service sector in our country has also affected the structure of consumer spending. The share of services in the structure of consumer spending of the population of the country in 2005 was only $15.4 \%$. However, the rate of this figure is not less than $50-60 \%$ in developed countries 7 .

The establishment of tourist centers in mountainous and rural areas will help to develop these areas and improve the living standards of the population.

In recent years, in many countries, especially in our country, it has become customary for people living in cities to go to the countryside on weekends. This has led to the fact that the rural population is required to have a second specialization related to tourism and to build and operate tourist complexes in the picturesque areas of the village. This, in turn, will improve the living conditions of the rural population.

With the expansion of tourism, the number of service enterprises, including hotels, will continue to grow. In addition, the field related to the development of tourism includes many enterprises, businesses (restaurants, transport, entertainment facilities, etc.), which operate during the tourist season. Their turnover increases depending on the number of tourists.

To determine the place of tourism and hotel services in the service system, we provide the following data (Table 1.1).

Monograph. - T .: "Economy" Publishing House, 2013. - 44 pages.

${ }^{6}$ Social development and living standards of the population in Uzbekistan 2004. T .: Goskomstat of Uzbekistan. 2005.-C 72.

7 Resolution of the President of the Republic of Uzbekistan dated April 17, 2006 "On measures to accelerate the development of the service sector in the
Table 1.1

Structural changes in the field of services in the Republic of Uzbekistan for $2010-2011^{8}$
Republic of Uzbekistan in 2006-2010". "People's word". April 18, 2006. p.1

8 "2012 will be a year that will take the development of our country to a new level." It was calculated by the authors of the study complex on the main results of 2011 and the speech of the President of the Republic of Uzbekistan Islam Karimov at a meeting of the Cabinet of Ministers on the priorities of socioeconomic development of Uzbekistan in 2012. 
The American Journal of Applied sciences (ISSN - 2689-0992)

\begin{tabular}{|c|c|c|c|c|c|c|c|}
\hline \multirow[t]{2}{*}{ № } & & \multicolumn{3}{|c|}{ 2010-year } & \multicolumn{3}{|c|}{ 2011-year } \\
\hline & Types of services & $\begin{array}{l}\text { billion } \\
\text { soums. }\end{array}$ & $\begin{array}{l}\text { Growth } \\
\text { (percent) }\end{array}$ & $\begin{array}{c}\text { Composition } \\
\text { (percent) }\end{array}$ & $\begin{array}{l}\text { billion } \\
\text { soums. }\end{array}$ & $\begin{array}{l}\text { Growth } \\
\text { (percent) }\end{array}$ & $\begin{array}{c}\text { Composition } \\
\text { (percent }\end{array}$ \\
\hline & Services, total & 32749,8 & 113,2 & 100,00 & 41083,4 & 125,4 & 100,00 \\
\hline & Including: & & & & & & \\
\hline 1. & Trade services & 6134,4 & 120,9 & 18,73 & 8607,5 & 140,3 & 20,95 \\
\hline 2. & $\begin{array}{l}\text { Transportation } \\
\text { services }\end{array}$ & 10547 & 113 & 32,20 & 12350,2 & 117,1 & 30,06 \\
\hline 3. & $\begin{array}{l}\text { Communication and } \\
\text { information services }\end{array}$ & 2062,5 & 128,7 & 6,30 & 2630 & 127,5 & 6,40 \\
\hline 4. & $\begin{array}{c}\text { Financial and banking } \\
\text { services }\end{array}$ & 2753,8 & 119,4 & 8,41 & 3507,5 & 127,4 & 8,54 \\
\hline 5. & $\begin{array}{c}\text { Tourist and excursion } \\
\text { services }\end{array}$ & 44,7 & 115,3 & 0,14 & 64,1 & 143,4 & 0,16 \\
\hline 6. & Hotel services & 97,5 & 107,8 & 0,30 & 112,4 & 115,3 & 0,27 \\
\hline 7. & Utilities & 3852,1 & 99 & 11,76 & 4780,5 & 124,1 & 11,64 \\
\hline 8. & Household services & 561,4 & 122,8 & 1,71 & 534,5 & 95,3 & 1,30 \\
\hline 9. & Car repair services & 314,2 & 124,6 & 0,96 & 367,8 & 117,1 & 0,90 \\
\hline 10. & Others & 6382,2 & 116,6 & 19,49 & 8128,9 & 127,4 & 19,79 \\
\hline
\end{tabular}


Tourism has a significant economic growth in our country. In 2011, it increased by $143.4 \%$. However, the development of the hotel industry lags behind tourism, reaching 115.3\% this year. This shows that the growth of all services in the Republic of Uzbekistan (125.4\%) was more tourism services. The second most developed services were trade services, which grew by $140.3 \%$. The growth rate of communication and information services, which is one of the leading services, was $127.5 \%$ during this period.

Tourism belongs to the service sector and is one of the fastest growing sectors of the economy. The rapid growth of tourism in Uzbekistan will have a positive impact on the

economy by providing large amounts of foreign exchange earnings, as well as the development of the country's tourism industry. Because if we look at the history of tourism, it is based on hospitality. This has been and remains the ancient custom of mankind. Previously, guests were greeted in their own home, apartment. Now its content has changed. Usually, people have to live away from home for days, weeks, months. He will need the support and help of "strangers". This is done through hospitality.

According to the Uzbek dictionary, hospitality means "hospitality, behavior, hospitality". ${ }^{8}$. Nowadays, hospitable visits are also made in connection with spending the night and relaxing in hotels, not in someone's apartment.

\footnotetext{
${ }^{9}$ Explanatory dictionary of the Uzbek language. J. 2 E-M

10 Papiryan G.A. Management in the hospitality industry (hotels and restaurants). M .: OAO NPO: Izdvo "Ekonomika", 2000., Walker Dj. Introduction to hospitality: Textbook / per. s angl. M .: UNITI, 1999., Basics of management of enterprises and
}

Because of this, the terms hospitality and tourism are used interrelatedly in the economic literature. ${ }^{9}$. Scientists of our country use the term "mehmonnavozlik(hospitality)" instead of hospitality ${ }^{10}$. It is also clear that revealing the nature of the concept of hospitality is important in the study of theoretical issues of tourism. This requires the development of a definition of each concept. Hospitality is now a type of service provided in tourism and also has some business characteristics. Based on this content, we found it appropriate to define hospitality as follows: Hospitality is a set of relationships related to the provision of services such as accommodation, catering, transportation, excursions, conferences, entertainment.

Hospitality as a part of tourism is of great importance for the development of this industry. Due to this, the establishment of the hospitality industry will also ensure the sustainable development of the industry. With this in mind, it was considered expedient to develop a definition of the hospitality industry as well. The hospitality industry is a business activity aimed at the formation and development of the market of services related to the implementation of hospitality.

The term "tourism and hospitality industry" is widely used in the tourism literature ${ }^{11}$. It acknowledges that hospitality is seen as a broader and more general concept than tourism. It is said that its task is to meet not only the needs of tourists, but also the needs of all consumers. In our opinion, tourism and

organizations of the hospitality industry / Under red.A.Braymera. - M., 1994.

11 Mamatkulov X.M. Explanatory dictionary of tourism and service. Samarkand: SIES, 2010. - $151 \mathrm{p}$. ${ }^{12}$ Tourism and hospitality. Textbook / Ed. prof., d.e.n. A.D. Chudnovskogo. - M $\therefore$ Association of Authors and Publishers "Tandem". EKMOS Publishing. 2001, - 400 p. 
hospitality cannot be considered in isolation. Due to this, the hospitality industry cannot be considered separately. Because tourists are also consumers with specific needs depending on the purpose of the trip.

The hospitality industry has historically been shaped by various hotel businesses, i.e. accommodation services. In general, a hotel is a building that is furnished for visitors and consists of rooms that are ready for living. In modern conditions, a hotel is an enterprise that provides hotel services to citizens, as well as individual tourists or special groups. But there are also different views on this concept. Summarizing them, it is expedient to give the hotel the following description:

A hotel is a special farm designed to provide the necessary additional services, creating the necessary conditions for temporary residence, ie rest and work of guests (tourists). In our opinion, this description fully reflects the content of the hotel.

The modern hotel business offers consumers not only accommodation and catering services, but also a wide range of services such as transport, communications, leisure excursion services, medicine, sports, beauty salons. In practice, the hotel business performs key functions in the tourism and hospitality industry, offering consumers a hotel product with complex features. All sectors and elements of the tourism and hospitality industry are involved in the formation and sale of this product. In this context, we found it expedient to consider the hotel business independently as an integral part of the tourism and hospitality industry. Therefore, some issues have been studied to some extent in close connection with the tourism and hospitality industry.
As a result of the development of science and technology, the hospitality industry has become a powerful industry employing millions of employees who create convenience for people. The hospitality industry combines different areas of human professional activity: tourism, hotel and restaurant business, catering, recreation and entertainment services, organization of conferences and exhibitions, sports, museums, exhibitions, excursions, as well as professional areas in the field of hospitality. takes

Due to the fact that tourism belongs to the service sector and is one of the fastest growing sectors of the economy, its rapid growth in our country has a positive impact on the economy by providing large foreign exchange earnings and contributes to the development of the tourism industry. In recent years, along with the increase in supply in the hotel market, there has been a decline in demand for accommodation services. This situation has led to increased competition. One of the main ways to gain a competitive advantage in the hotel business is to offer high quality services to competitors.

Provision of regional tourist services in Uzbekistan requires certain costs. It can be seen that the share of hotel expenses in their structure is high (Table 1.2).

The data in this table provide sufficient information to assess the state of development of tourist excursion services in the regions of the Republic of Uzbekistan in 2007-2011. The provision of tourist services in the country was mainly carried out in 200720011. However, in 2010 it was planned to increase this service by $127.5 \%$. However, this figure was fulfilled by $110.6 \%$. This growth trend was influenced by the next wave of the global financial and economic crisis that continued in those years. Because the influx of tourists to 
our country has slowed down for a while. A similar situation has occurred in many provinces. Only in the Republic of Karakalpakstan, Andijan, Jizzakh, Tashkent and Kashkadarya regions can it be seen that it has exceeded the plan. Although the plans for tourist excursion services have been implemented throughout the country, in many regions (such as Bukhara, Syrdarya, Khorezm) they are systematically implemented.

Table 1.2

Development status of tourist excursion services in the regions of the Republic of Uzbekistan in 2007-2011 (in comparable prices) ${ }^{12}$

\begin{tabular}{|c|c|c|c|c|c|c|c|c|c|c|c|}
\hline \multicolumn{12}{|c|}{ Percentage compared to last year } \\
\hline \multirow[t]{3}{*}{ № } & \multirow{3}{*}{$\begin{array}{l}\text { Name of } \\
\text { regions }\end{array}$} & \multicolumn{10}{|c|}{ Growth of service volume } \\
\hline & & \multicolumn{2}{|c|}{ 2007-year } & \multicolumn{2}{|c|}{ 2008-year } & \multicolumn{2}{|c|}{ 2009-year } & \multicolumn{2}{|c|}{ 2010- year } & \multicolumn{2}{|c|}{ 2011- year } \\
\hline & & Plan & $\begin{array}{l}\text { in } \\
\text { practi } \\
\text { ce }\end{array}$ & plan & $\begin{array}{c}\text { in } \\
\text { practi } \\
\text { ce }\end{array}$ & plan & $\begin{array}{l}\text { in } \\
\text { practi } \\
\text { ce }\end{array}$ & plan & $\begin{array}{l}\text { in } \\
\text { practi } \\
\text { ce }\end{array}$ & plan & in \\
\hline & $\begin{array}{l}\text { Republic of } \\
\text { Uzbekistan }\end{array}$ & 119,3 & 122,3 & 121,3 & 126,3 & 123,4 & 130,4 & 127,5 & 110,6 & 117,7 & 127,3 \\
\hline & Including: & & & & & & & & & & \\
\hline 1. & $\begin{array}{c}\text { Republic of } \\
\text { Karakalpaksta } \\
\text { n. }\end{array}$ & 109,1 & 129,3 & 110,5 & 167,1 & 111,3 & 126,7 & 113,5 & 125 & 105,3 & 205,6 \\
\hline 2. & Andijan region & 115,6 & 483,6 & 118 & 138,1 & 119,5 & 128,8 & 120 & 132 & 116,5 & 105,3 \\
\hline 3. & $\begin{array}{l}\text { Bukhara } \\
\text { region }\end{array}$ & 119 & 118,7 & 120 & 127,2 & 120,2 & 101,2 & 128 & 105 & 108,0 & 103,2 \\
\hline 4. & $\begin{array}{l}\text { Jizzakh } \\
\text { region }\end{array}$ & 118 & 218,2 & 118,5 & 177,4 & 120 & 106,2 & 122 & 125 & 104,0 & 71,3 \\
\hline 5. & $\begin{array}{c}\text { Kashkadarya } \\
\text { region }\end{array}$ & 118 & 123,4 & 119,5 & 126 & 124 & 116,3 & 130 & 130 & 112,0 & 112,3 \\
\hline
\end{tabular}

13"2012 will be a year that will take the development of our country to a new level." It was calculated by the authors of the study complex on the main results of 2011 and the speech of the President of the
Republic of Uzbekistan Islam Karimov at a meeting of the Cabinet of Ministers on the priorities of socioeconomic development of Uzbekistan in 2012. 
The American Journal of Applied sciences

(ISSN - 2689-0992)

\begin{tabular}{|c|c|c|c|c|c|c|c|c|c|c|c|}
\hline 6. & Navoi region & 122 & 170,5 & 123,5 & 139,1 & 124 & 130,7 & 125 & 107 & 105,0 & 109,0 \\
\hline 7. & $\begin{array}{l}\text { Namangan } \\
\text { region }\end{array}$ & 115 & 117,7 & 118 & 0 & 122 & 127,6 & 125 & 115 & 103,0 & 119,2 \\
\hline 8. & $\begin{array}{l}\text { Samarkand } \\
\text { region }\end{array}$ & 118 & 128 & 122 & 158,4 & 125 & 141,8 & 129 & 103 & 112,0 & 112,0 \\
\hline 9. & $\begin{array}{c}\text { Surkhandary } \\
\text { a region }\end{array}$ & 116 & 226,6 & 116,5 & 125 & 118 & 175,2 & 120 & 115 & 112,0 & 105,6 \\
\hline 10. & $\begin{array}{l}\text { Syrdarya } \\
\text { region }\end{array}$ & 110 & 18,3 & 120 & 0 & 130,5 & 113,1 & 135 & 2,6 & - & - \\
\hline 11. & $\begin{array}{l}\text { Tashkent } \\
\text { region }\end{array}$ & 120 & 127 & 122 & 177,4 & 123,5 & 191 & 125 & 140 & 108,0 & 122,3 \\
\hline 12. & $\begin{array}{l}\text { Fergana } \\
\text { region }\end{array}$ & 118 & 118,1 & 119,5 & 113,2 & 122 & 123 & 123 & 103 & 105,0 & 105,3 \\
\hline 13. & $\begin{array}{l}\text { Khorezm } \\
\text { region }\end{array}$ & 115 & 126,2 & 120 & 200 & 121,1 & 105,1 & 130 & 105 & 105,4 & 112,4 \\
\hline 14. & Tashkent city & 121 & 124,4 & 122 & 118,3 & 123,5 & 135,3 & 128 & 115 & 120,5 & 136,7 \\
\hline
\end{tabular}

It is clear that tourism services will need to be planned based on the real capabilities of each region.

It should be noted that the State Program for the development of tourism in our country and in each of its regional branches has been developed. Very large are focused on fulfilling the parameters provided in these programs. All governmental and non-governmental organizations in the field are engaged in this. Due to this, there are positive changes in the development trend of tourist excursion services. These types of services will also develop rapidly in the future. Because of the great attention paid to this area, the relevant infrastructure has been created and is being improved. All this is a great opportunity for the development of tourism in the future.

\section{REFERENCES}

1. Kudratov G'.H., Musaev H.H. Uzbekistan's investment policy and its role in the development of the tourism services market. // Socio-economic problems of tourism market development in Uzbekistan. Monograph. - T .: "Economy" Publishing House, 2012. - Pages 288-289. 
2. Pardaev MK, Khalikulov AN, Rakhimov HA "Problems of increasing efficiency in the hotel industry" (T .: "Economy" Publishing House, 2013. - p. 44).

3. Resolution of the President of the Republic of Uzbekistan dated April 17, 2006 "On measures to accelerate the development of the service sector in the Republic of Uzbekistan in 2006-2010". "People's word". April 18, 2006. p.1.

4. Statistical Bulletin of Uzbekistan. 2005. Page 5.

5. Khalikulov N.N. Opportunities to improve the quality and efficiency of service in hotels. Dissertation for the degree of Candidate of Economic Sciences. SamISI. 2011. - Page 11

6. Pardaev M.Q., Khalikulov A.N., Rahimov H.A. Problems of increasing efficiency in hotel farms. Monograph. - T .: "Economy" Publishing House, 2013. - 44 pages.

7. Social development and living standards of the population in Uzbekistan 2004. T .: Goskomstat of Uzbekistan. 2005.-C 72.

8. Explanatory dictionary of the Uzbek language. J. 2 E-M

9. Papiryan G.A. Management in the hospitality industry (hotels and restaurants). $M \quad:$ OAO NPO: Izd-vo "Ekonomika", 2000., Walker Dj. Introduction to hospitality: Textbook / per. s angl. M .: UNITI, 1999., Basics of management of enterprises and organizations of the hospitality industry / Under red.A.Braymera. - M., 1994.

10. Mamatkulov X.M. Explanatory dictionary of tourism and service. Samarkand: SIES, 2010. - $151 \mathrm{p}$.
11. Tourism and hospitality. Textbook / Ed. prof., d.e.n. A.D. Chudnovskogo. - $M$.: Association of Authors and Publishers "Tandem". EKMOS Publishing. 2001, - 400 p. 